\title{
ПАРТНЕРСЬКИЙ ФОРУМ «ОСВІТА УКРАЇНИ 2021: СТРАТЕГІЧНІ ЦІЛІ ТА ПРІОРИТЕТНІ НАПРЯМИ»
}

Доповідь президента НАПН України, 9 лютого 2021 р., м. Київ, Україна https://doi.org/10.37472/2707-305X-2021-3-1-3-1

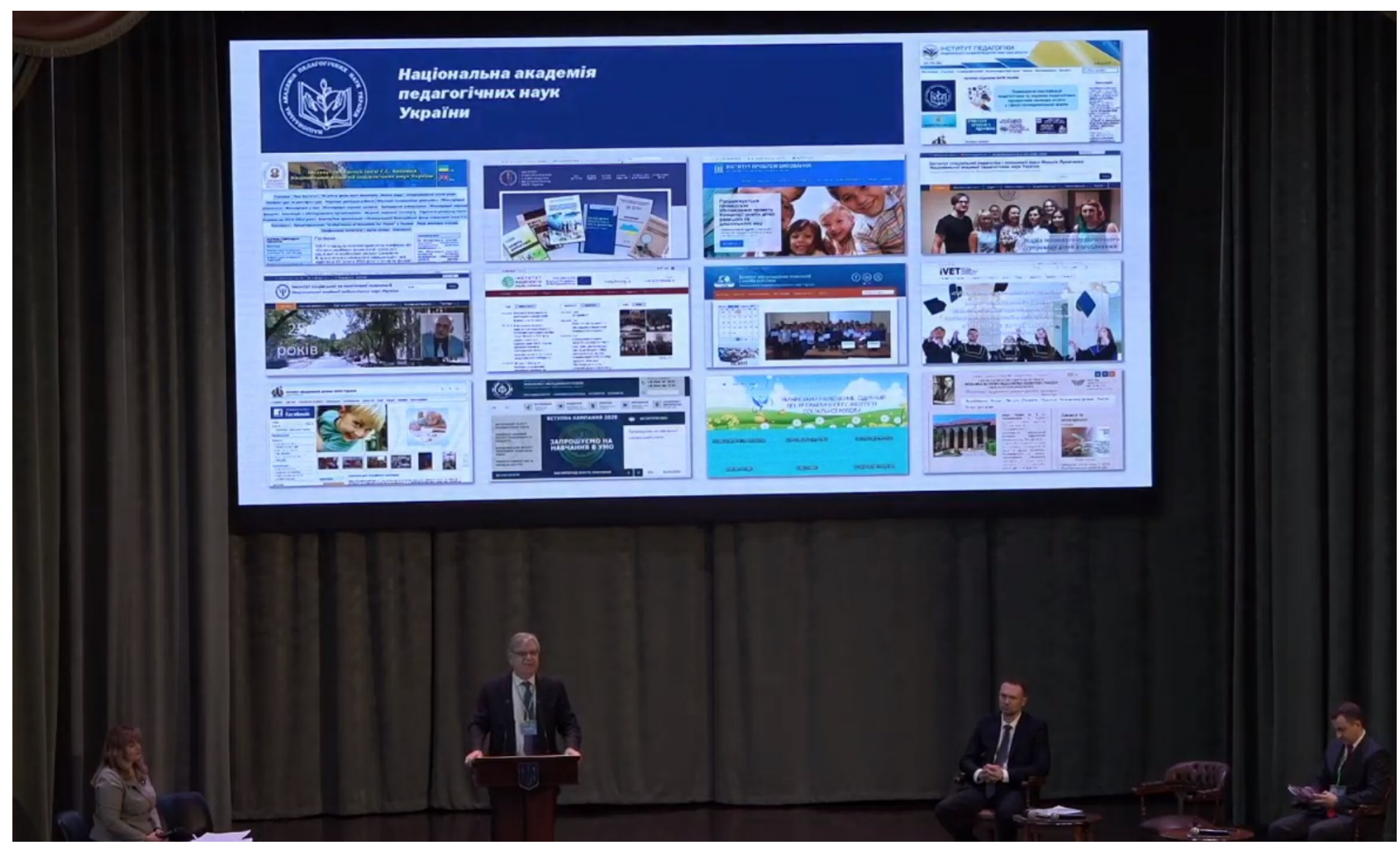

\section{KPEMEHЬ}

\section{Василь Григорович}

доктор фрілософрських наук, профресор, дійсний член (академік) НАН України і НАПН України, президент Національної академії педагогічних наук України, президент Товариства «Знання» України, м. Київ, Україна

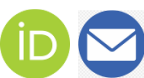

Анотація. У виступі на Партнерському форумі «Освіта України 2021 стратегічні цілі та пріоритетні напрями» обгрунтовано ключові зміни у сучасному цивілізаційному розвитку та їх об'єктивний вплив на формування інновачійної, конкурентоспроможної, «цифрової», патріотичної людини. Розкрито напрями плідної співпраці з Міністерством освіти і науки України та Комітетом Верховної Ради України з питань освіти, науки та інновацій. Представлено найбільш вагомі результати діяльності НАПН України; охарактеризовано істотні проблеми, зокрема в повній загальній середній освіті, які потребують всебічного осмисленого та практичного вирішення, запропоновано шляхи їх розв'язання.

Ключові слова: Начіональна академія педагогічних наук України; повна загальна середня освіта; наукова діяльність; освіта України; педагогіка; психологія; науково-методичний супровід; інноваційна людина.

Участь Президента України в сьогоднішньому форумі свідчить про розуміння очільником держави першочергового значення освіти для розвитку України. I це дійсно так. Наука як сфера, що продукує нові знання, й освіта, що через навчання дітей олюднює ці знання, робить їх діяльнісними - саме ці сфери можуть забезпечити динамічний прогрес суспільства. 
Але $є$ одна передумова - освіта повинна готувати людину до життя і діяльності не для минулого часу, як у нас це ще нерідко буває, а для сучасних умов. А вони під впливом об'єктивного розвитку цивілізації змінюються.

Перше. Світ вступив в інноваційний тип прогресу, коли відбувається швидка зміна ідей, знань, технологій, що вимагає формування інноваційної людини - $з$ інноваційним мисленням, інноваційною культурою і здатністю до інноваційного типу діяльності. Людини, яка б могла творити нове, сприймати нове, відрізняти нове позитивне від негативного.

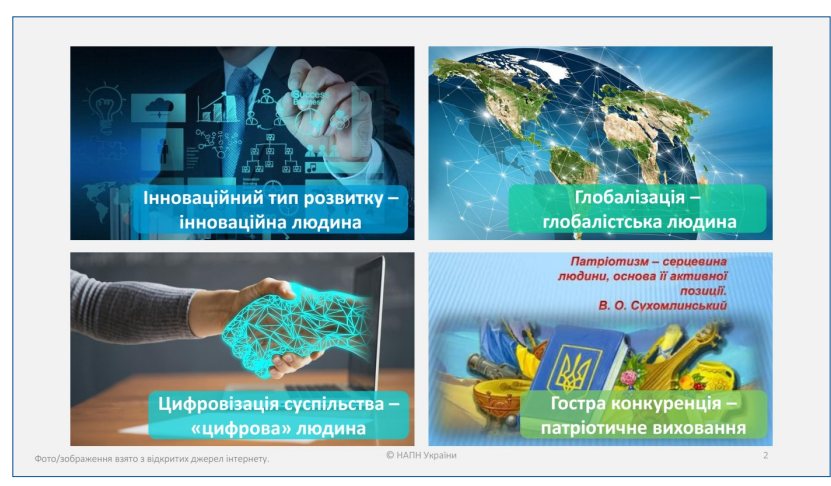

Друге. Відбувається цифровізація суспільства. Звідси завдання - формування по суті «цифрової» людини, яка б була компетентною у нових обставинах життя і діяльності.

Tpemє. Світ об'єктивно стає все більш глобалізованим і успіх країни в цих умовах залежить від здатності людини працювати на світовому рівні, бути конкурентоспроможною в міжнародному вимірі. Із цього погляду слід готувати глобалістську людину, але безумовно патріота України.

Четверте. Глобальний світ - це світ гострої конкуренції, а то й протиборства. Тому залишається архіважливим національне єднання, патріотичне виховання. Бо лише єдиний народ зможе найкраще усвідомити свої національні інтереси в різних сферах життя і відстояти їх, а то й захистити власну незалежність, як це стало актуальним для України.

На ці та інші вимоги часу ми повинні обов'язково орієнтуватися в усій освітянській діяльності, у здійсненні будь-яких змін. Залишаючи при цьому осердям реформування освіти, принцип дитиноцентризму - тобто максимальне наближення навчання і виховання дитини до ії суті, конкретних здібностей і талантів, життєвих планів і психологічних особливостей.

Ці та інші сучасні підходи лежать в основі діяльності Національної академії педагогічних

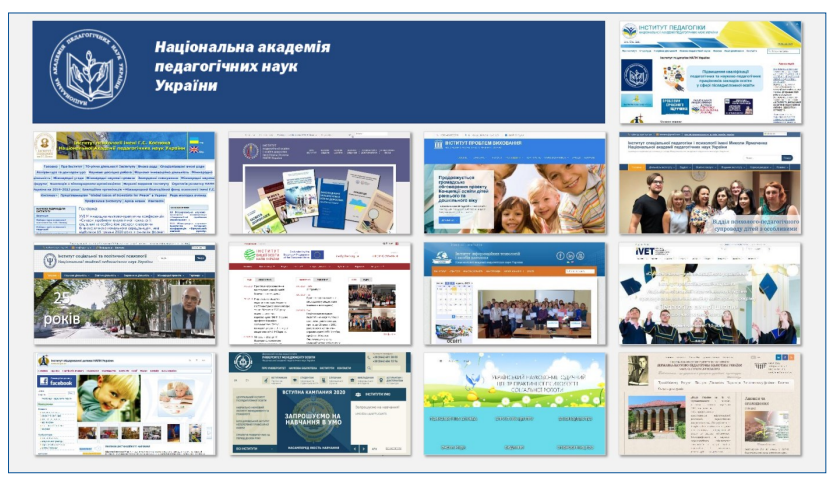

наук України щодо наукового і методичного забезпечення розвитку освіти.

Така робота стала значно більш ефективною 3 нинішнім керівництвом Міністерства освіти і науки України, яке очолив фаховий, досвідчений, сучасний і відповідальний керівник.

За цей час підготовлено і підписано трирічну програму спільної діяльності міністерства і академії (НАПН України, 2020), спільно підготовлено і затверджено Кабінетом Міністрів України Державний стандарт базової середньої освіти (59 класи), спільно підготовлено проєкти законів «Про професійну (професійно-технічну) освіту» та «Про освіту дорослих», спільно підготовлено «Стратегію розвитку вищої освіти України на 20212031 роки», йде активна робота з підготовки типових освітніх програм для базової школи (Вітренко \& Ворона, 2020; Луговий, 2020а; Луговий, 2020b; Луговий, 2020с; Луговий, 2020d; Лук'янова, 2020; Ляшенко, 2020).

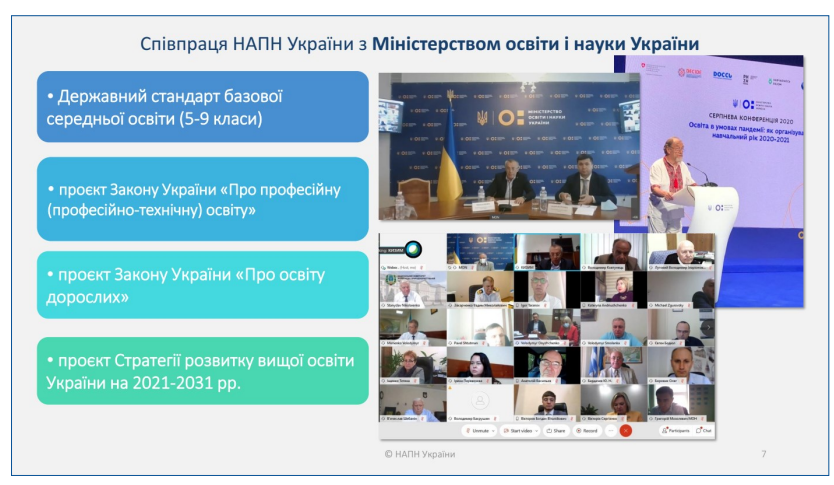

Тісну співпрацю з установами академії налагоджено на рівні департаментів міністерства.

Академія вітає рішучі і конструктивні дії міністерства з реформування освітньої і наукової сфери, зокрема загальної середньої освіти, чому присвячений і Меморандум про співпрацю між Міністерством освіти і науки України і Національною академією педагогічних наук України, який буде підписаний сьогодні.

Наша академія налагоджує тісну співпрацю $з$ Комітетом Верховної Ради України з питань 
освіти, науки та інновацій. Спільно з підкомітетом, який очолює народний депутат В.А. Воронов, розроблено Концепцію освіти дітей раннього та дошкільного віку (Сисоєва \& Рейпольська, 2020). Вчені академії щороку проводять, переважно для Верховної Ради України, наукову експертизу близько 100 нормативно-правових актів.

В останній період НАПН України істотно вдосконалила свою діяльність.

По-перше. Підвищено публікаційну ефективність вчених установ академії і членів НАПН України. У 2020 р. здійснено понад 330 публікацій у виданнях, що індексуються Scopus i Web of Science Core Collection, що вчетверо більше, ніж у $2018 p$.

Багатократно збільшилася кількість свідоцтв на реєстрацію авторського права.

Вченим академії присуджено державні премії в галузі освіти (2018р.) та в галузі науки і техніки (2019 р.).

По-друге. Активізовано роботу з молодими вченими. У 2020 р. ними додатково виконано сім прикладних досліджень. В останні роки премії Президента України та стипендії Уряду отримали 13 молодих вчених.

По-mpemє. 32020 р. зміщено акцент з фундаментальних на прикладні дослідження. Нині 60 \% досліджень є прикладними. Започатковані конкурсні річні дослідження для розв'язання проблем, які потребують невідкладного розгляду.

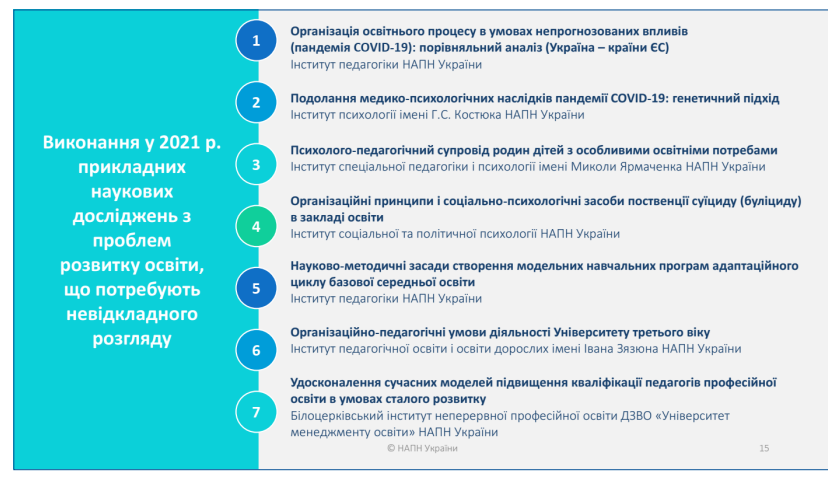

По-четверте. За конкурсом Національного фонду досліджень у 2020 р. перемогу отримали три проєкти установ НАПН України загальним фінансуванням понад 14 млн грн.

По-n'яте. За результатами досліджень у 20182020 рр. вченими підготовлено 94 підручники, майже всі з грифом МОН України, 122 посібники, 66 навчальних програм і 9 освітніх стандартів. Загалом щороку видається понад 3 тис. праць.

По-шосте. Йде активний процес цифровізації роботи академії. Створено Електронну бібліотеку
НАПН України, у якій розміщено 23 тис. праць вчених академії, що завантажувалися понад 7 млн разів користувачами із 134 країн світу.

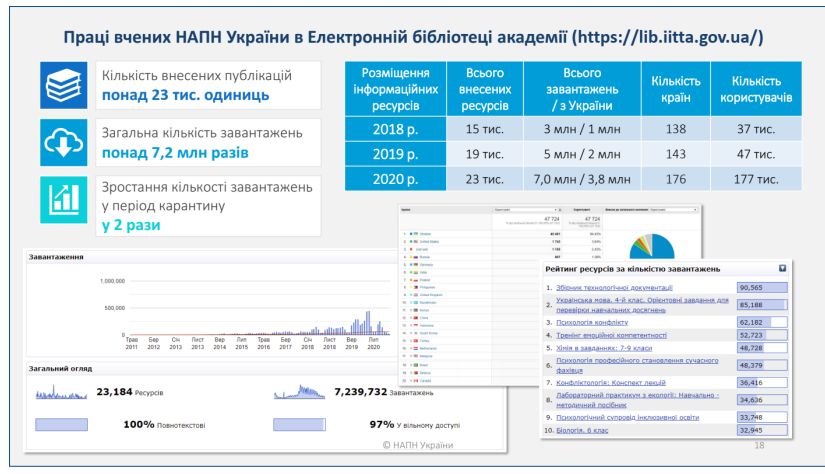

Електронний журнал «Інформаційні технології і засоби навчання» індексується у Web of Science Core Collection. У 2020 р. здійснено 1 млн переглядів користувачами з України та зарубіжних країн. Це видання входить у топ-10 журналів наукової періодики України.

Розпочато створення Електронної енциклопедії освіти типу Вікіпедії.

По-сьоме. Розширено міжнародну діяльність шляхом участі у майже 50 проєктах і програмах. Зокрема Інститутом вищої освіти НАПН України розпочато європейський проєкт співпраці вартістю 1,5 млн євро, у якому Інститут виступає ґрантоотримувачем. Проєкт спрямований на підтримку діяльності переміщених університетів.

Особливу увагу вчені академії приділили допомозі освітянам в умовах коронавірусу. Це і матеріали «Використання системи комп'ютерного моделювання в умовах дистанційного навчання», це і цифрові зошити для практичних і лабораторних робіт з математики, фізики, біології і хімії, це і активна праця вчених у соціальних мережах із роз'яснення використання IKT в освітньому процесі. Також підготовлено оглядове видання «Відповідь світової спільноти на виклики COVID-19 в освіті» та багато іншого.

Низку актуальних науково-аналітичних матеріалів направлено в МОН України та профільний комітет Верховної Ради України.

У загальній середній освіті $€$ досить багато проблем, які потребують всебічного аналізу. Заслуговують на увагу такі.

Перша. Конституцією України передбачено обов'язкову повну загальну середню освіту. Це безумовно прогресивна норма. Ії̈ мають лише декілька європейських країн. Хоча зазначу, що фактично середню освіту там отримують більше 90 \% дітей. Але ж ми знаємо, що не всі діти через 
певні причини бажають навчатися, скажімо, в старшій школі. Освітяни ж змушені спонукати їх це робити чи в школі, чи в профтехзакладі. I там, i там такі діти перебувають формально і часто заважають навчатися іншим. Разом із тим, на базі 9-ти класів вони можуть отримати потрібну їм і суспільству професію і самореалізуватись. А чи не слід нам трактувати норму Конституції про обов'язковість повної загальної середньої освіти як таку, що може бути пролонгована впродовж життя людини? Тобто держава створить умови кожній людині для ії отримання тоді, коли вона виявить бажання це зробити.

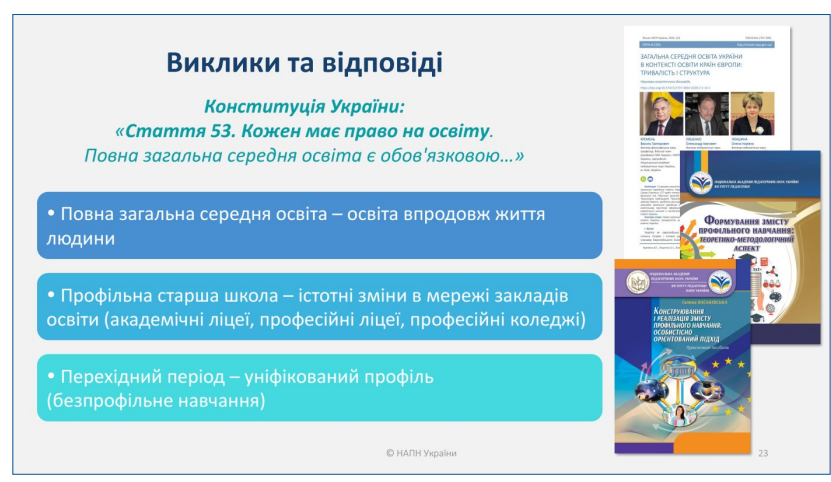

Друге. Я є послідовним прибічником профільної старшої школи. Це можуть підтвердити ті, хто пам'ятає часи мого керівництва Міністерством освіти і науки України в 2000-2005 pp.

Нинішньою реформою школи передбачено запровадження профільної старшої школи 3 2027 року. Для ії успішного здійснення необхідно провести суттєві зміни в мережі закладів освіти, зокрема створити академічні ліцеї, оптимізувати мережу професійних ліцеїв і професійних коледжів. Зробити це скрізь і вчасно дуже важко. До того ж $\in$ місцевості, як наприклад, гористі, сільські, що дуже малонаселені, де об'єктивно важко це зробити взагалі. Забезпечити ж профільне навчання з врахуванням інтересів дітей в школі, де є один 10 і т.д. клас, неможливо.

Пропозиція - передбачити для таких випадків, хоча б на певний період, можливість уніфікованого профілю, тобто іншими словами безпрофільне навчання. Це краще, ніж займатися псевдопрофільністю на шкоду дитині. До того ж, це 6 заспокоїло громадську думку щодо побоювань чи зможуть діти навчатися в 10 класі. Подібна конструкція була у нас в реформуванні на початку 2000-х років.

Системний і грунтовний аналіз освіти буде здійснено в «Національній доповіді про стан і перспективи розвитку освіти України», що

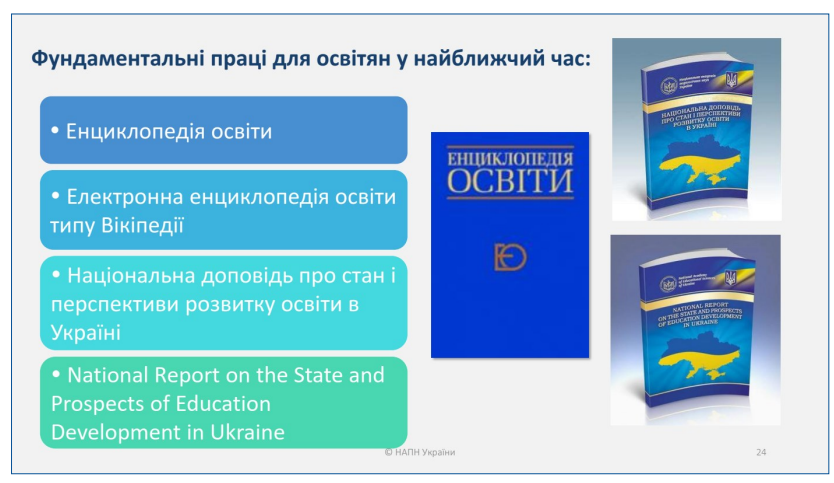

готується вченими академії до 30-річчя незалежності України. Такі доповіді ми традиційно готуємо кожні п'ять років і видаємо українською та англійською мовами.

Національна академія педагогічних наук України і надалі буде робити все можливе для якісного наукового і методичного забезпечення розвитку освіти та всебічно допомагати освітянам у такій важливій їхній діяльності, зокрема у сфері загальної середньої освіти.

\section{СПИСОК ВИКОРИСТАНИХ ДЖЕРЕЛ}

Електронна бібліотека НАПн України. (n.d.). https:// lib.iitta.gov.ua/

Вітренко, Ю.М., \& Ворона, В.О. (2020). Стратегія розвитку вищої освіти в Україні на 2021-2031 роки: економічний аспект. Вісник Національної академії педагогічних наук України, 2(2). https:// doi.org/10.37472/2707-305X-2020-2-2-11-6

Кремень, В.Г. (2021). Законодавче забезпечення i шляхи реформування Національної академії наук та національних галузевих академій наук. Вісник Національної академії педагогічних наук України, 3(1). https://doi.org/10.37472/2707-305X-2021-3-1-15-1

Кремень, В.Г., Луговий, В.І., Топузов, О.М., Регейло, І.Ю., \& Базелюк, Н.В. (2020). Про виконання Програми спільної діяльності Міністерства освіти і науки України та Національної академії педагогічних наук України на 2017-2020 роки. Вісник Національної академії педагогічних наук України, 2(2). https://doi.org/10.37472/2707-305X-2020-2-2-2-3

Кремень, В.Г., Ляшенко, О.І., \& Локшина, О.І. (2020). Загальна середня освіта України в контексті освіти країн Європи: тривалість і структура. Вісник Національної академії педагогічних наук України, 2(2). https://doi.org/10.37472/2707-305X-2020-2-2-14-1

Локшина, О.І., Глушко, О.З., Джурило, А.П., Кравченко, С.М., Нікольська, Н.В., Тименко, М.М., \& Шпарик, О.М. (упоряд.). (2020). Відповідь світової спільноти на виклики COVID-19 в освіті (лютийчервень 2020 р.) : оглядове видання (О.І. Локшина, наук. ред.). Національна академія педагогічних наук України, Інститут педагогіки НАПН України. Київ: Авторитет. https://doi.org/10.32405/978-96697763-0-4-2020-36

Луговий, В.І. (2020а). Проблема освітньої якості в стратегії розвитку вищої освіти в Україні. Вісник Національної академії педагогічних наук України, 2(2). https://doi.org/10.37472/2707-305X-2020-2-2-11-1 
Луговий, В.І. (2020b). Поточний стан вищої освіти в Україні: проблеми, причини, перспективи. Вісник Національної академії педагогічних наук України, 2(2). https://doi.org/10.37472/2707-305X-2020-2-2-11-2

Луговий, В.І. (2020c). Реалізація науково-педагогічної функції викладача в контексті стратегії розвитку вищої освіти в Україні. Вісник Національної академії педагогічних наук України, 2(2). https:// doi.org/10.37472/2707-305X-2020-2-2-11-3

Луговий, В.І. (2020d). Модернізація фінансування вищої освіти України: баланс досконалості механізмів, можливостей і мережі. Вісник Національної академії педагогічних наук України, 2(2). https:// doi.org/10.37472/2707-305X-2020-2-2-11-4

Лук'янова, Л.Б. (2020). Законодавче забезпечення освіти дорослих в Україні: сучасний стан та перспективи розвитку. Вісник Начіональної академії педагогічних наук України, 2(2). https:// doi.org/10.37472/2707-305X-2020-2-2-1-2

Ляшенко, О.І. (2020). Презентація проєкту Державного стандарту базової середньої освіти: чим новий стандарт відрізняється від попередніх? Вісник Національної академії педагогічних наук України, 2(2). https://doi.org/10.37472/2707-305X-2020-2-2-11-5

Міністерство освіти і науки України. (2021, 9 лютого). 9 лютого - Партнерський форум «Освіта України 2021: стратегічні чілі та пріоритетні напрями» [Відео]. YouTube. https://youtu.be/ QLGkzN602n8

Національна академія педагогічних наук України. (n.d.). Головна. http://naps.gov.ua/

Національна академія педагогічних наук України. (2020). Програма спільної діяльності Міністерства освіти і науки України та Національної академії педагогічних наук України на 2021-2023 роки. http://naps.gov.ua/ua/activities/research/mon23/

Сисоєва, С.О., \& Рейпольська, О.Д. (2020). Концепція освіти дітей раннього та дошкільного віку: новий погляд. Вісник Національної академії педагогічних наук України, 2(1). https://doi.org/10.37472/2707305X-2020-2-1-2-2

\section{PARTNER FORUM “EDUCATION OF UKRAINE 2021: STRATEGIC GOALS AND PRIORITIES”}

Report of the President of the National Academy of Educational Sciences of Ukraine, February 9, 2021, Kyiv, Ukraine

\section{Vasyl Kremen}

DSc in Philosophy, Professor, Full Member (Academician) of NAS of Ukraine and NAES of Ukraine, President, National Academy of Educational Sciences of Ukraine; President, Society "Knowledge" of Ukraine, Kyiv, Ukraine

Abstract. The key changes in modern civilisation development and their objective influence on the formation of an innovative, competitive, "digital", patriotic person are grounded in the report at the Partner Forum "Education of Ukraine 2021: Strategic Goals and Priorities". The directions of effective cooperation with the Ministry of Education and Science of Ukraine and Committee of the Verkhovna Rada of Ukraine on Education, Science and Innovations are enlightened. The most important results of the National Academy of Educational Sciences of Ukraine activities are presented; the significant problems, in particular in the complete general secondary education, requiring a comprehensive meaningful and practical solution, are characterised; the ways to solve them are suggested.

Keywords: National Academy of Educational Sciences of Ukraine; complete general secondary education; research activities; education in Ukraine; pedagogy; psychology; scientific and methodological support; innovative person. 